\begin{tabular}{c} 
PEDIOMATERNAL \\
NURSING JOURNAL \\
Vol. 5, No. 2, September 2019 \\
Journal Homepage: https://e-journal.unair.ac.id/PMNJ// \\
\hline
\end{tabular}

Original Research

\title{
Pengaruh Perawatan Metode Kanguru Terhadap Respon Fisiologis Bayi Berat lahir Rendah
}

\section{(The Effect of Kangaroo Care on the Physiological Response of Low Birth Weight Babies)}

\author{
Rahayu Catur Ria Wati ${ }^{1}$, Risa Etika ${ }^{2}$, dan Esti Yunitasari ${ }^{3}$ \\ ${ }^{1}$ Program Studi Kebidanan Fakultas Kedokteran, Universitas Airlangga, Surabaya, Indonesia \\ 2 Departemen Ilmu kesehatan Anak Fakultas Kedokteran, Universitas Airlangga, Surabaya, Indonesia \\ ${ }^{3}$ Departemen Keperawatan Maternitas dan Anak Fakultas Keperawatan, Universitas Airlangga, Surabaya, Indonesia
}

\author{
ARTICLE HISTORY \\ Received: May 21, 2019 \\ Accepted: July 30, 2019

\section{KEYWORDS} \\ LBWB; heart rate; kangaroo \\ care; oxygen saturation; \\ temperature
}

\section{CORRESPONDING AUTHOR}

Rahayu Catur Ria Wati rahayu.catur.ria-

2017@fk.unair.ac.id

Program Studi Kebidanan,

Fakultas Kedokteran

Universitas Airlangga, Surabaya, Indonesia

Cite this as:

\begin{abstract}
Introduction: Low Birth Weight Babies (LBWB) is one of the causes of the high Neonatal Mortality Rate in Indonesia. This occurs because LBWB has non-optimal temperature regulation centers, thin-brown and subcutaneous fat tissue, inadequate muscle growth, and organ immaturity. Kangaroo Care (KC) is expected to be an effective and efficient solution to keep LBW in a stable condition. This study aimed to determine the effect of KC on the physiological responses of LBWB.
\end{abstract}

Methods: This study is a pre-experimental design with one group pretest-posttest research design. The sample was obtained with a total sampling technique and the size was 21 LBWB. The independent variable in this study was KC; carried out for 3 days with a frequency of 2 times a day and 90 minutes per KC. Meanwhile, the dependent variable was the physiological responses of LBWB which consisted of temperature, heart rate, and oxygen saturation. The instrument used was $\mathrm{KC}$ observation sheets with Wilcoxon signed rank test for the data analysis.

Results: The study showed that the temperature increased from $36.5^{\circ} \mathrm{C}$ to $36.9^{\circ} \mathrm{C}$; the heart rate increased from $135 \mathrm{x} /$ minute to $147 \mathrm{x} /$ minute; the oxygen saturation increased from $93 \%$ to $98 \%$. The results of the Wilcoxon signed rank test on the pretest-posttest data revealed that the temperature $p=0.002$, heart rate frequency $p=0.001$, and oxygen saturation $\mathrm{p}=0.000$. The increased physiological responses were still in the range of normal.

Conclusion: The KC can maintain the stability of LBWB physiological responses. By that, it is recommended for parents to continue KC as a home-care for LBWB until the weight reached 2500 grams.

Wati, R, C, R., Etika R., \& Yunitasari, E. (2019). Pengaruh Perawatan Metode Kanguru Terhadap Respon Fisiologis Bayi Berat lahir Rendah. Pediomaternal Nurs. J., 5(2), 175-182.

\section{PENDAHULUAN}

Bayi Berat Lahir Rendah (BBLR) adalah bayi yang lahir dengan berat kurang dari 2500 gram tanpa memperhatikan masa kehamilan (1). Prevalensi BBLR diperkirakan $15 \%$ dari seluruh kelahiran di dunia dan sering terjadi di negara-negara berkembang atau sosio-ekonomi rendah. Secara statistik menunjukkan $90 \%$ kejadian BBLR didapatkan di negara berkembang dan angka kematiannya 35 kali lebih tinggi dibandingkan dengan bayi dengan berat lahir lebih dari 2500 gram (2).
Data Millenium Development Goals (MDG's) 2015 mengungkapkan angka kematian di bawah usia 5 tahun, $45 \%$ terjadi pada periode neonatal dengan prevalensi komplikasi preterm 16\%, komplikasi terkait persalinan $11 \%$, sepsis $7 \%$, abnormalitas kongenital 5\%, faktor lainnya 3\% dan pneumonia 3\% (3). Berdasarkan hasil Survei Demografi dan Kesehatan Indonesia (SDKI) tahun 2012, Angka Kematian Neonatus (AKN) pada tahun 2012 sebesar 19 per 1.000 kelahiran hidup (4). Target Sustainable Development Goals (SDG's) pada tahun 2030 diharapkan dapat mengurangi AKN hingga 12 per 1000 kelahiran hidup dan menurunkan $1 / 3$ angka 
kematian bayi prematur akibat penyakit tidak menular melalui tindakan pencegahan dan perawatan (5). Kejadian prematur sering dikaitkan dengan kondisi berat bayi lahir rendah.

Setiap bayi yang baru lahir akan mengalami proses transisi yang sangat besar dari lingkungan dalam ke luar rahim. Pada bayi BBLR, beberapa kondisi yang terjadi adalah pusat pengaturan suhu belum optimal, jaringan lemak coklat dan subkutan tipis, pertumbuhan otot-otot yang belum memadai serta imaturitas organ (6), kondisi seperti ini menjadikan BBLR mengalami respon fisiologis yang berbeda dengan bayi dengan berat lahir normal

Secara umum, BBLR membutuhkan perawatan dalam inkubator untuk mendapatkan respon fisiologis yang baik dalam menjalani masa transisi dari kehidupan dalam ke luar rahim, sehingga diperlukan infrastruktur yang mahal. Beberapa penelitian menunjukkan bahwa kematian BBLR dapat dicegah menggunakan intervensi yang tidak mahal, mudah dilakukan dan tepat guna yaitu dengan Perawatan metode Kanguru (PMK) $(7,8)$.

Dari hasil studi pendahuluan yang dilakukan peneliti dengan melakukan penelusuran data terhadap BBLR di RSUD dr. R. Soedarsono Kota Pasuruan didapatkan data BBLR bulan Juni-Juli 2018 sebanyak 32 bayi dari total 205 bayi baru lahir (16\%) angka ini cukup tinggi jika dibandingkan dengan prevalensi BBLR di Indonesia yaitu 10,2\% (9). BBLR yang telah dilakukan PMK intermiten sejumlah 22 dari 32 bayi (69\%). Upaya PMK terhadap BBLR telah dilaksanakan di rumah sakit ini, namun belum optimal. Tujuan dari penelitian ini adalah untuk menganalisis pengaruh PMK terhadap respon fisiologis yang meliputi suhu tubuh, frekuensi denyut jantung dan saturasi oksigen BBLR.

\section{METODE}

\subsection{Desain}

Jenis penelitian yang digunakan adalah pre experimental design..

\subsection{Populasi, sampel, dan sampling}

Populasi dalam penelitian ini adalah seluruh BBLR yang dirawat di ruang perinatalogi RSUD dr. R. Soedarsono Kota Pasuruan pada bulan JanuariFebruari 2019 yaitu sejumlah 33 BBLR. Sampel dalam penelitian ini adalah BBLR pada bulan JanuariFebruari 2019 yang memenuhi kriteria sebagai sampel penelitian, dengan kriteria inklusi: BBLR yang memiliki catatan rekam medis yang lengkap, serta ibu/ ayah BBLR dalam kondisi sehat (tidak demam) dan kriteria eksklusi: BBLR yang atas pertimbangan klinis Dokter Penanggung Jawab Pasien (DPJP) tidak diperkenankan untuk dilakukan PMK (bayi dengan gangguan nafas, bayi dengan kelainan kongenital, serta bayi sepsis) serta ibu/ ayah tidak berkenan dengan PMK. Teknik pengambilan sampel yang digunakan yaitu dengan cara total sampling didapatkan jumlah sampel sebesar 21 BBLR. Lokasi penelitian di ruang perinatalogi RSUD $\mathrm{dr}$. $\mathrm{R}$.
Soedarsono Kota Pasuruan. Waktu pelaksanaan penelitian Bulan Januari-Februari 2019.

\subsection{Variabel}

Variabel independen yaitu PMK sedangkan variabel dependen adalah respon fisiologis yang meliputi suhu tubuh, frekuensi denyut jantung, dan saturasi oksigen BBLR.

\subsection{Instrumen}

Instrumen pada penelitian ini menggunakan lembar observasi PMK (berupa cheklist langkah-langkah PMK yang disesuaikan dengan standar prosedur operasional PMK di Ruang Perinatalogi RSUD dr. R. Soedarsono Kota Pasuruan), suhu diukur dengan termometer digital merk $\mathrm{ABN}$, frekuensi denyut jantung dan saturasi oksigen diukur dengan pulse oxymetri merk mindray. Untuk data penujang lain yang meliputi data ibu dan bayi digunakan lembar pengumpul data.

\subsection{Prosedur}

Peneliti dan perawat/ bidan (asisten peneliti) melakukan persamaan persepsi tentang PMK dan prosedur penelitian, pengambilan sampel dimulai oleh peneliti atau asisten peneliti yaitu memperkenalkan diri kepada orang tua/ keluarga responden, menjelaskan tujuan dan prosedur penelitian dan meminta kesediaan dan tanda tangan persetujuan oleh responden. Peneliti mengukur suhu, frekuensi denyut jantung, dan saturasi oksigen BBLR sebelum dilakukan PMK, kemudian dicatat dalam lembar observasi PMK, kemudian peneliti/ asisten peneliti mengajarkan dan mendampingi ibu/ keluarga dalam melakukan PMK sesuai Standar Prosedur Operasional (SPO) PMK yang tercatat dalam lembar observasi PMK, setelah dilakukan PMK selama 90 menit, peneliti mengukur kembali suhu, frekuensi denyut jantung, dan saturasi oksigen BBLR, kemudian dicatat dalam lembar observasi PMK (kegiatan ini dilakukan 2x sehari selama 3 hari). Untuk data lain yang meliputi data ibu dan bayi, diperoleh melalui telusur rekam medis ibu dan bayi (data sekunder), serta hasilnya dicatat dalam lembar pengumpul data

\subsection{Analisis}

Analisis univariat pada penelitian ini dilakukan pada masing-masing variabel yang diteliti dengan menggunakan distribusi frekuensi. Karena data respon fisiologis pre-test dan post-test berdistribusi tidak normal, maka data deskriptif menggunakan median dan analisis bivariat menggunakan wilcoxon sign rank test untuk mengetahui perbedaan respon fisiologis BBLR pre test dan post test dengan menggunakan perangkat lunak SPSS dan tingkat kemaknaan $\alpha=0,05$.

\subsection{Ethical Clearance}

Ethical clearance yang digunakan yaitu kelaikan etik yang didapatkan dari tim komite etik penelitian kesehatan fakultas kedokteran Universitas Airlangga 
Tabel 1. Distribusi Karakteristik Orang Tua Responden yang Melakukan PMK di Ruang Perinatalogi RSUD dr. R. Soedarsono Kota Pasuruan Bulan Januari- Februari 2019 (n=21)

\begin{tabular}{|c|c|c|c|}
\hline Kategori & & $\mathbf{n}$ & $\%$ \\
\hline \multirow[t]{3}{*}{ Usia Ibu } & $<20$ tahun & 1 & 5 \\
\hline & 20-35 tahun & 15 & 71 \\
\hline & $>35$ tahun & 5 & 24 \\
\hline \multirow[t]{3}{*}{ Pendidikan Ibu } & SD & 6 & 28 \\
\hline & SMP & 10 & 48 \\
\hline & SMA & 5 & 24 \\
\hline \multirow[t]{3}{*}{ Pendidikan Ayah } & SD & 6 & 29 \\
\hline & SMP & 8 & 38 \\
\hline & SMA & 7 & 33 \\
\hline \multirow[t]{2}{*}{ PekerjaanIbu } & TidakBekerja & 20 & 95 \\
\hline & Bekerja & 1 & 5 \\
\hline \multirow[t]{5}{*}{ Pekerjaan Ayah } & Petani & 3 & 14 \\
\hline & Nelayan & 4 & 19 \\
\hline & Pedagang & 2 & 9 \\
\hline & Swasta & 11 & 53 \\
\hline & PNS & 1 & 5 \\
\hline \multirow[t]{5}{*}{ ParitasKe- } & 1 & 7 & 33 \\
\hline & 2 & 10 & 48 \\
\hline & 3 & 2 & 9 \\
\hline & 4 & 1 & 5 \\
\hline & 5 & 1 & 5 \\
\hline \multirow[t]{4}{*}{ IMT Ibu } & Underweight & 1 & 5 \\
\hline & Normal & 7 & 33 \\
\hline & Overweight & 12 & 57 \\
\hline & Obese & 1 & 5 \\
\hline
\end{tabular}

Surabaya dengan nomor sertifikat kelaikan etik yaitu 3/EC/KEPK/FKUA/2019. Menjaga kerahasiaan pasien dengan baik dengan cara tidak menyebutkan nama tetapi inisial. Data yang diperoleh dan hasil penelitian hanya digunakan untuk kepentingan penelitian saja.

\section{Hasil}

Karakteristik orang tua responden yang melakukan PMK di Ruang Perinatalogi RSUD dr. R. Soedarsono Kota Pasuruan. Ibu-ibu usia 20-35 tahun merupakan sebagian besar responden yang melakukan PMK dengan jumlah 15 orang (71\%). Ibu dengan pendidikan SMP dengan jumlah 10 orang (48\%) adalah yang terbanyak. Ayah responden dengan pendidikan SMP dengan jumlah 8 orang (38\%) juga yang terbanyak. Ibu yang tidak bekerja merupakan mayoritas responden yang melakukan PMK dengan jumlah 20 orang (95\%), sedangkan untuk ayah responden, sebagian bekerja swasta yaitu 11 orang (53\%). Ibu-ibu dengan paritas ke-2 yaitu sejumlah 10 orang $(48 \%)$ adalah yang terbanyak dan ibu yang memiliki IMT overweight merupakan sebagian besar responden yang melakukan PMK dengan jumlah 12 orang (57\%) [Tabel 1].

Karakteristik responden bayi yang mendapatkan PMK di Ruang Perinatalogi RSUD dr. R. Soedarsono Kota Pasuruan. Bayi yang menjadi responden hampir seluruhnya lahir di Rumah Sakit dengan jumlah 20 BBLR (95\%) dan BBLR tersebut mayoritas lahir normal (pervagina) yaitu sebanyak 17 responden (81\%). BBLR yang menjadi responden hampir seluruhnya mengalami penyulit dalam persalinan, antara lain karena partus prematur yaitu 7 responden (33\%) dan KPP 7 responden (33\%). Ditinjau dari usia kehamilan, bayi yang lahir pada usia kehamilan prematur (<37 minggu) merupakan sebagian besar responden dengan jumlah 14 bayi (67\%). PMK ini hampir seluruhnya dilakukan pada bayi usia $0-3$ hari yaitu 17 bayi (81\%) dan bayi dengan berat badan 1500-2500 gram merupakan mayoritas responden dengan jumlah 18 bayi (86\%). [Tabel 2].

Rata-rata perubahan suhu tubuh BBLR dalam 3 hari selama dilakukan PMK, PMK dilakukan 2x sehari, sehingga ada 6 data hasil pegamatan, pada setiap pengamatan dilakukan pengukuran suhu tubuh BBLR baik pre test (sebelum PMK) dan post test (setelah PMK). Gambar 1 menunjukkan bahwa, rata-rata suhu tubuh BBLR mengalami peningkatan selama dilakukan PMK, namun masih dalam rentang normal (36,5-37,5 을 [Gambar 1].

Rata-rata perubahan frekuensi denyut jantung BBLR dalam 3 hari selama dilakukan PMK, PMK dilakukan $2 \mathrm{x}$ sehari, sehingga ada 6 data hasil pegamatan, pada setiap pengamatan dilakukan pengukuran frekuensi denyut jantung BBLR baik pre test (sebelum PMK) dan post test (setelah PMK). Gambar 2 menunjukkan bahwa, rata-rata frekuensi denyut jantung BBLR mengalami peningkatan selama dilakukan PMK, namun masih dalam rentang normal (120 - $160 \mathrm{x} /$ menit) [Gambar 2].

Rata-rata perubahan saturasi oksigen BBLR dalam 3 hari selama dilakukan PMK, PMK dilakukan 
Tabel 2. Distribusi Karakteristik Responden Bayi yang Mendapatkan PMK di Ruang Perinatalogi RSUD dr. R. Soedarsono Kota Pasuruan Bulan Januari-Februari 2019 (n=21)

\begin{tabular}{llcc}
\hline Kategori & & n & \% \\
\hline TempatPersalinan & RS (Rumah Sakit) & 20 & 95 \\
& PMB (Praktek Mandiri Bidan) & 1 & 5 \\
Cara Persalinan & Pervagina & 17 & 81 \\
& SectioCaesaria (Sc) & 4 & 19 \\
PenyulitPersalinan & PEB (Pre Eklamsi Berat) & 2 & 10 \\
& KPP (Ketuban Pecah Prematur) & 7 & 33 \\
& PartusPrematur & 7 & 33 \\
& Gemelli & 2 & 10 \\
UsiaKehamilan & PJT (Pertumbuhan Janin Terhambat) & 3 & 14 \\
& Prematur (<37 minggu) & 14 & 67 \\
UsiaBayiSaatdilakukan PMK & 7 & 33 \\
BB Lahir & Aterm (37- 40 minggu) & 17 & 81 \\
& 0-3 hari & 4 & 19 \\
& B hari & 1 & 5 \\
& Bayi Berat Lahir Amat Sangat Rendah (BBLASR) < 1000 gram & 2 & 9 \\
& Bayi Berat Lahir Sangat Rendah (BBLSR) 1000-1500 gram & 18 & 86 \\
\hline
\end{tabular}

2x sehari, sehingga ada 6 data hasil pegamatan, pada setiap pengamatan dilakukan pengukuran saturasi oksigen BBLR baik pre test (sebelum PMK) dan post test (setelah PMK). Gambar 3 menunjukkan bahwa, rata-rata saturasi oksigen BBLR mengalami peningkatan selama dilakukan $\mathrm{PMK}$, namun masih dalam rentang normal (90-99\%) [Gambar 3].

Hasil uji wilcoxon suhu tubuh BBLR sebelum dan setelah dilakukan PMK selama 3 hari di Ruang Perinatalogi RSUD dr. R. Soedarsono Kota Pasuruan Bulan Januari-Februari 2019, ada 2 BBLR dengan suhu menurun dan 19 BBLR suhu meningkat. Hasil uji menunjukkan $p$ value $0,002, p$ value $<\alpha(0,05)$, sehingga dapat diartikan bahwa ada perbedaan suhu tubuh BBLR sebelum dan setelah dilakukan PMK atau dengan kata lain, PMK berpengaruh terhadap suhu tubuh BBLR pada tingkat kepercayaan 95\% [Tabel 3].

Hasil uji wilcoxon frekuensi denyut jantung BBLR sebelum dan setelah dilakukan PMK selama 3 hari di Ruang Perinatalogi RSUD dr. R. Soedarsono Kota Pasuruan Bulan Januari-Februari 2019, ada 2 BBLR dengan frekuensi denyut jantung menurun dan 19 BBLR dengan frekuensi denyut jantung meningkat. Hasil uji menunjukkan p value $0,001, p$ value $<\alpha$ $(0,05)$, sehingga dapat diartikan bahwa ada perbedaan frekuensi denyut jantung BBLR sebelum dan setelah dilakukan PMK atau dengan kata lain, PMK berpengaruh terhadap frekuensi denyut jantung BBLR pada tingkat kepercayaan 95\% [Tabel 4].

Hasil uji wilcoxon saturasi oksigen BBLR sebelum dan setelah dilakukan PMK selama 3 hari di Ruang Perinatalogi RSUD dr. R. Soedarsono Kota Pasuruan Bulan Januari-Februari 2019, 21 BBLR mengalami peningkatan saturasi oksigen. Hasil uji menunjukkan $\mathrm{p}$ value $0,000, \mathrm{p}$ value $<\alpha(0,05)$, sehingga dapat diartikan bahwa ada perbedaan saturasi oksigen BBLR sebelum dan setelah dilakukan PMK atau dengan kata lain, PMK berpengaruh terhadap saturasi oksigen BBLR pada tingkat kepercayaan 95\% [Tabel 5].

\section{PEMBAHASAN}

4.1 Perubahan Suhu Tubuh BBLR Sebelum dan Setelah Dilakukan PMK

Berdasarkan hasil penelitian, diketahui bahwa median suhu tubuh BBLR sebelum dilakukan PMK adalah $36,5^{\circ} \mathrm{C}$ dengan rentang minimum-maksimum $(36,3-38,0)^{\circ} \mathrm{C}$ dan setelah dilakukan PMK suhu tubuh BBLR naik menjadi $36,9^{\circ} \mathrm{C}$ dengan rentang minimummaksimum $(36,6-37,1)^{\circ} \mathrm{C}$. Terjadi peningkatan suhu tubuh BBLR sebesar $0,4^{\circ} \mathrm{C}$ dan rentang suhu menjadi lebih kecil (lebih stabil) dan nilai $p$ value 0,002 yang artinya ada pengaruh yang signifikan PMK terhadap suhu tubuh BBLR.

Suhu tubuh BBLR sebelum dilakukan PMK sebagian besar berada pada suhu tubuh normal, hal ini terjadi karena BBLR yang dirawat di Ruang Perinatalogi mendapatkan perawatan khusus menggunakan inkubator, serta tanda-tanda vital yang terpantau dengan baik. Jika dikaitkan dengan tempat persalinan BBLR, maka mayoritas responden yang lahir di RS juga menjadi salah satu faktor yang mendukung terjadinya kestabilan suhu BBLR sebelum dilakukan PMK. Penelitian menunjukkan sekitar dua pertiga bayi rujukan berada dalam kondisi tidak stabil saat masuk rawat di rumah sakit dan jenis kondisi tidak stabil yang tersering adalah hipotermi (10), sehingga dengan merujuk BBLR intra uterine (masih dalam rahim) akan dapat menjaga kestabilan suhu BBLR. Serta dari karakteristik responden yang sebagian besar lahir pervagina, juga memungkinkan untuk dilakukan kontak kulit ke kulit lebih dini (11)

Dalam penelitian ini, ada 1 responden BBLR mengalami hipertermi dengan suhu $38^{\circ} \mathrm{C}$ dan 2 responden mengalami hipotermi ringan yaitu $36,3^{\circ} \mathrm{C}$ dan $36,4^{\circ} \mathrm{C}$. Pengaturan termoregulasi pada BBLR ini belum optimal, BBLR akan cenderung mudah mengalami hipotermi maupun hipertermi. Pusat pengaturan tubuh berada di hipotalamus di mana 


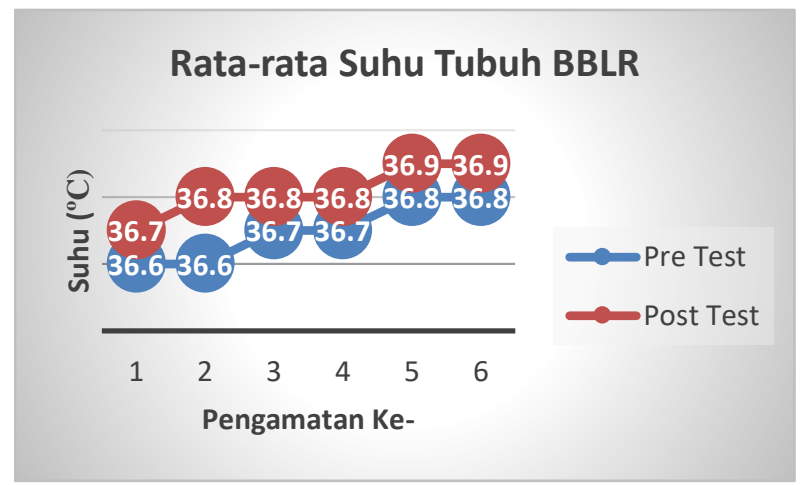

Gambar 1. Grafik Perubahan Suhu Tubuh BBLR dalam 3 Hari Selama dilakukan PMK di Ruang Perinatalogi RSUD dr. R. Soedarsono Kota Pasuruan Bulan JanuariFebruari 2019

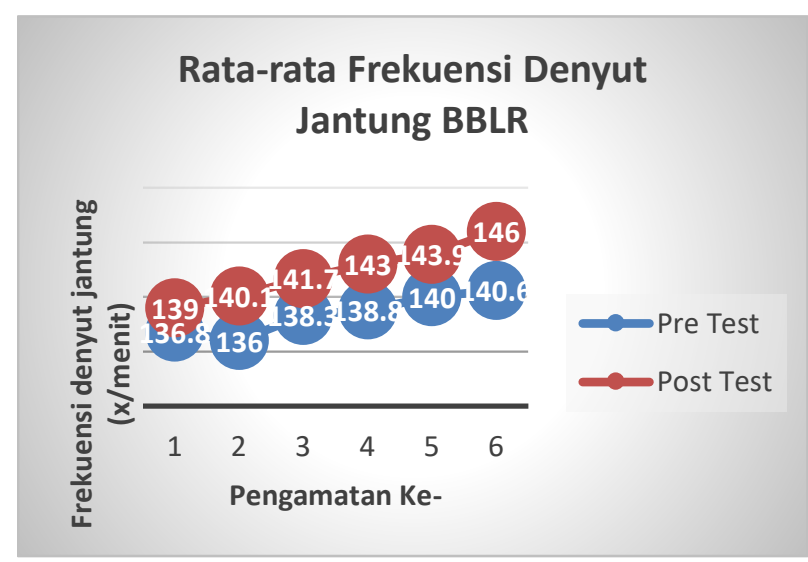

Gambar 2. Grafik Perubahan Frekuensi Denyut Jantung BBLR dalam 3 Hari Selama dilakukan PMK di Ruang Perinatalogi RSUD dr. R. Soedarsono Kota Pasuruan Bulan Januari-Februari 2019

\section{Rata-rata Saturasi Oksigen BBLR}

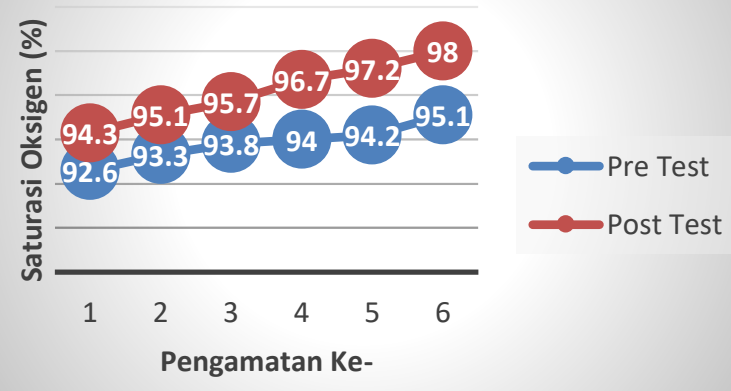

Gambar 3. Grafik Perubahan Saturasi Oksigen BBLR dalam 3 Hari Selama dilakukan PMK di Ruang Perinatalogi RSUD dr. R. Soedarsono Kota Pasuruan Bulan Januari-Februari 2019

pusat ini terutama mengatur agar suhu inti (core thempreature) tetap stabil. Pada beberapa keadaan tertentu seperti dalam keadaan hipotalamus yang belum berkembang (pada bayi kurang bulan), adanya perdarahan intra kranial, terjadi asfiksia, hipoglikemia, jejas jalan lahir dan lain-lain, fungsi pusat ini akan terganggu (6).
Suradi dan Yanuarso (2000) menambahkan bahwa salah satu ciri BBLR adalah mengalami hipotermi, di mana BBLR mempunyai suhu yang tidak stabil dan cenderung hipotermi (12). Stres dingin dapat meningkatkan angka kematian dan menghambat pertumbuhan sedangkan hipertermi dan suhu yang berfluktuasi dapat menimbulkan apneu. Suhu yang cenderung hipotermia disebabkan karena produksi panas kurang dan kehilangan panas yang tinggi. Panas kurang diproduksi karena sirkulasi yang masih belum sempurna, respirasi masih lemah, konsumsi oksigen yang rendah, otot yang belum aktif serta asupan makanan yang kurang. Kehilangan panas terjadi akibat dari permukaan tubuh yang relatif lebih luas dan lemak subkutan yang kurang, terutama lemak coklat (brown fat). Hipotermia dapat mengakibatkan komplikasi jangka pendek berupa asidosis, hipoglikemia dan gangguan pembekuan darah serta peningkatan resiko untuk distress pernapasan. Apabila berkepanjangan hipotermia dapat menyebabkan edema, sklerema, pernapasan hebat (terutama perdarahan paru), dan ikterus. Selain itu pada BBLR juga memiliki ciri bayi mengalami apneu. Kelainan ini terjadi akibat ketidakmatangan paru dan susunan saraf pusat. Apneu didefinisikan sebagai periode tak bernapas selama lebih dari 20 detik dan disertai bradikardi. Kelainan ini dapat ditemukan pada pemantauan yang teliti dan terus-menerus. Semua bayi dengan masa kehamilan kurang dari 34 minggu harus secara rutin dan terus menerus dipantau sampai apneu itu hilang selama satu minggu.

Beberapa penelitian menyebutkan bahwa PMK sangat baik untuk mencegah BBLR mengalami hipotermi (13). Observasi perubahan suhu tubuh BBLR sangat dianjurkan, karena ada kemungkinan bayi menjadi kepanasan. BBLR yang kepanasan akan mengakibatkan peningkatan metabolisme dan asupan oksigen, penurunan efisiensi metabolisme, dan mempengaruhi kestabilan fisiologis tubuh.

Penelitian lain menunjukkan bahwa penggunaan inkubator dan PMK sama-sama efektif untuk mencegah BBLR mengalami hipotermi $(14,15)$. sehingga meskipun BBLR tidak ditempatkan dalam inkubator, respon fisologis BBLR akan tetap stabil dengan PMK. Dengan PMK, jika bayi kedinginan, suhu kulit ibu otomatis akan naik dua derajat untuk menghangatkan bayinya dan sebaliknya jika bayi kepanasan, suhu kulit ibu akan turun satu derajat untuk mendinginkan bayinya. Kulit ibu bersifat termoregulator atau termal sinkroni bagi suhu tubuh bayi (16).Penelitian menunjukkan bahwa tidak ada perbedaan signifikan antara PMK yang dilakukan baik ibu maupun ayah terhadap respon fisiologis bayi. PMK yang dilakukan baik oleh ibu maupun ayah sama-sama aman dan efektif (17).

4.2 Perubahan Suhu Tubuh BBLR Sebelum dan Setelah Dilakukan PMK

Berdasarkan hasil penelitian, diketahui bahwa median frekuensi denyut jantung BBLR sebelum dilakukan PMK adalah $135 \mathrm{x} /$ menit dengan rentang 
Tabel 3. Hasil Analisis Uji Wilcoxon Suhu Tubuh BBLR Sebelum dan Setelah dilakukan PMK di Ruang Perinatalogi RSUD dr. R. Soedarsono Kota Pasuruan Bulan Januari-Februari 2019 (n=21)

\begin{tabular}{lll}
\hline & Median (Minimum-Maksimum) & p value \\
\hline Suhu sebelum dilakukan PMK & $36,5(36,3-38,0)$ & 0,002 \\
Suhu setelah dilakukan PMK & $36,9(36,6-37,1)$ & \\
\hline
\end{tabular}

Tabel 4. Hasil Analisis Uji Wilcoxon Frekuensi Denyut Jantung BBLR Sebelum dan Setelah dilakukan PMK di Ruang Perinatalogi RSUD dr. R. Soedarsono Kota Pasuruan Bulan Januari-Februari 2019 (n=21)

\begin{tabular}{lll}
\hline & Median (Minimum-Maksimum) & p value \\
\hline Frekuensi denyut jantung sebelum dilakukan PMK & $135(128-168)$ & 0,001 \\
Frekuensi denyutj antung setelah dilakukan PMK & $147(143-156)$ & \\
\hline
\end{tabular}

Tabel 5. Hasil Analisis Uji Wilcoxon Frekuensi Denyut Jantung BBLR Sebelum dan Setelah dilakukan PMK di Ruang Perinatalogi RSUD dr. R. Soedarsono Kota Pasuruan Bulan Januari-Februari 2019 (n=21)

\begin{tabular}{lll}
\hline & Median (Minimum-Maksimum) & p value \\
\hline Saturasi oksigen sebelum dilakukan PMK & $93(91-94)$ & 0,000 \\
Saturasi oksigen setelah dilakukan PMK & $98(96-99)$ & \\
\hline
\end{tabular}

minimum-maksimum (128-168) x/menit dan setelah dilakukan PMK frekuensi denyut jantung BBLR naik menjadi $147 \mathrm{x} /$ menit dengan rentang minimummaksimum (143-156) x/menit. Terjadi peningkatan frekuensi denyut jantung BBLR sebesar $12 \mathrm{x} /$ menit dan rentang frekuensi denyut jantung menjadi lebih kecil (lebih stabil) dan nilai $p$ value 0,001 yang artinya ada pengaruh yang signifikan PMK terhadap frekuensi denyut jantung BBLR.

Sebelum dilakukan PMK, ada 1 bayi dengan takikardia, yaitu dengan frekuensi denyut jantung $168 \mathrm{x} /$ menit bersamaan dengan kondisi bayi yang mengalami hipertermi. Setelah dilakukan PMK, suhu tubuh bayi menjadi stabil, dan frekuensi denyut jantung bayi juga mengalami penurunan ke arah normal (stabil). Hal ini dapat dijelaskan karena selama dilakukan PMK, terjadi bonding antara BBLR dengan ibu/ ayah bayi, bayi merasa lebih tenang dan nyaman, sehingga frekuensi denyut jantung relatif lebih konstan/ stabil.Beberapa penelitian melaporkan bahwa PMK mempermudah pemberian ASI dan ibu lebih percaya diri dalam merawat bayi serta bounding attachment lebih baik yang berdampak positif pada psikologis ibu dan keluarga $(18,19)$.

Penelitian lan juga membuktikan bahwa PMK lebih memberikan dampak positif pada frekuensi denyut jantung BBLR serta mengurangi stres pada bayi (20). Hal ini dapat dijelaskan karena dengan PMK, terjadi bonding antara BBLR dengan ibu/ayah, secara otomatis mengurangi beberapa tindakan invasif yang biasa dilakukan terhadap BBLR ketika ditempatkan dalam inkubator .

Rangsangan suara dan sentuhan juga dapat diberikan selama PMK karena selama pelaksanaan PMK ibu dianjurkan untuk mengusap dengan lembut punggung bayi dan mengajak bayi berbicara untuk memberikan stimulasi sensori motorik, pendengaran, dan mencegah periodik apnea (21). PMK dapat menurunkan respon nyeri pada bayi, sehingga respon fisiologis pada bayi akan lebih stabil (22).

Penelitian menyebutkan bahwa PMK mempengaruhi stabilitas pengukuran suhu tubuh, frekuensi jantung, respirasi dan saturasi oksigen (23). Penelitian lain juga menemukan bahwa selama perawatan menggunakan metode kanguru, laju frekuensi denyut jantung bayi relatif lebih stabil dan konstan (24). Oleh karena itu, hasil dalam penelitian ini sudah sesuai dengan teori bahwasannya dengan dilakukan PMK, frekuensi denyut jantung BBLR akan menjadi stabil.

\subsection{Perubahan Saturasi Oksigen BBLR Sebelum dan Setelah Dilakukan PMK}

Berdasarkan hasil penelitian, diketahui bahwa median saturasi oksigen BBLR sebelum dilakukan PMK adalah 93\% dengan rentang minimummaksimum (91-94)\% dan setelah dilakukan PMK frekuensi denyut jantung BBLR naik menjadi 98\% dengan rentang minimum-maksimum (96-99)\%. Terjadi peningkatan saturasi oksigen BBLR sebesar $5 \%$ dan nilai $p$ value 0,000 yang artinya ada pengaruh yang signifikan PMK terhadap saturasi oksigen BBLR.

Saturasi oksigen cenderung mengalami penurunan apabila frekuensi denyut jantung mengalami bradikardi atau takikardi. Frekuensi denyut jantung yang lambat atau sangat cepat, akan mempengaruhi sirkulasi darah keseluruh tubuh. Sirkulasi darah yang tidak adekuat keseluruh tubuh, terutama bagian perifer, sehingga saturasi oksigen yang dipantau melalui pulse oxymetri menunjukkan kurang dari 90\%. (25) mengemukakan pendapat bahwa manfaat PMK diantaranya mampu sebagai stabilitas suhu tubuh, frekuensi denyut jantung dan perilaku bayi lebih baik, misalnya tangisan bayi berkurang dan sewaktu bangun terlihat lebih waspada. Selama perawatan menggunakan metode kanguru, laju frekuensi denyut jantung bayi relatif stabil dan konstan. Frekuensi denyut jantung BBLR yang mengalami kenaikan dapat terjadi akibat karena perubahan posisi dari horizontal menjadi posisi vertikal. Hal ini terjadi akibat pengaruh gaya gravitasi bumi. PMK mempunyai pengaruh posistif pada bayi, karena bayi merasakan detak jantung ibu, sehingga apabila bayi yang mengalami bradikardi akan terstimulasi agar jantungnya kembali berdenyut 
mengiringi detak jantung ibu. Suradi dan Yanuarso (2000) menambahkan bahwa Kangaroo Mother Care mempunyai manfaat bagi bayi yaitu terjadi kontak kulit bayi dan ibu membuat suhu tubuh bayi lebih stabil, pola pernafasan bayi menjadi lebih teratur, denyut jantung bayi lebih stabil, frekuensi menangis berkurang, lebih sering minum ASI dan lama menyusui lebih panjang serta kenaikan berat badan lebih baik.

Hasil penelitian lain juga melaporkan PMK menjaga kestabilan saturasi oksigen, penelitian menunjukkan bahwa PMK dapat meningkatkan saturasi oksigen BBLR (26). PMK secara bermakna mengurangi frekuensi napas dan meningkatkan saturasi oksigen. Hal ini dapat disebabkan oleh posisi bayi yang tegak, sehingga dipengaruhi oleh gravitasi bumi dan berefek pada ventilasi dan perfusi. Posisi tegak mengoptimalkan fungsi respirasi.

Hasil penelitian menunjukkan bahwa BBLR yang diberi PMK, terbukti efektif mempertahankan kestabilan respon fisiologis pada BBLR.Bayi yang mempunyai suhu tubuh normal, denyut jantung normal dan saturasi oksigen juga dalam kondisi normal, tidak akan mengalami stress fisiologis (20). Kondisi bayi yang demikian secara positif berdampak pada meningkatnya berat badan bayi secara signifikan, memiliki pengaruh positif dalam meningkatkan perkembangan kognitif. Waktu tidur bayi menjadi lebih lama yang ditandai dengan jumlah waktu terbangun bayi lebih rendah. Dampak bagi ibu diantaranya adalah mempercepat pengeluaran ASI dan meningkatkan keberhasilan menyusui (27)(28), stimulasi dini, kasih sayang antara ibu dan anak semakin meningkat, Menurunkan infeksi nosokomial dan memperpendek masa rawat inap (29). Menurunkan risiko kematian dini pada bayi, memperbaiki pertumbuhan pada bayi prematur dan memiliki pengaruh positif terhadap perkembangan motorik bayi (30)(31).

\section{KESIMPULAN}

Setelah dilakukan PMK terjadi peningkatan suhu, frekuensi denyut jantung dan saturasi oksigen namun tetap berada pada rentang normal. Dapat diartikan bahwa PMK dapat menjaga kestabilan respon fisiologis BBLR. Oleh karena itu diharapkan PMK dapat dilanjutkan sebagai perawatan bayi di rumah, hingga bayi mencapai berat 2500 gram.

\section{UCAPAN TERIMA KASIH}

Dengan ini saya mengucapkan terima kasih kepada Seluruh Jajaran dan Staf Fakultas Kedokteran dan Prodi Kebidanan Universitas Airlangga, Badan Kesatuan Bangsa dan Politik Kota Pasuruan, Direktur RSUD dr. R. Soedarsono Kota Pasuruan, Dokter Penanggung Jawab Pasien (DPJP), perawat dan bidan di Ruang Perinatalogi RSUD dr. R. Soedarsono Kota Pasuruan, seluruh responden yang telah memfasilitasi dan sangat membantu dalam penelitian ini serta keluarga dan rekan-rekan yang tidak dapat saya sebutkan satu per satu yang telah memberikan semangat serta dukungan dalam penyelesaian artikel ini.

\section{DAFTAR PUSTAKA}

1. Triana A, Damayanti IP, Afni R, Yanti JS. Buku Ajar Kebidanan Kegawatdaruratan Maternal dan Neonatal: Penuntun Belajar Mata Kuliah Asuhan Kebidanan Kegawatdaruratan Maternal dan Neonatal. Deepublish; 2015.

2. Silvia, Yelmi R EG. Pengaruh Perawatan Metode Kanguru Terhadap Perubahan Berat Badan Bayi Lahir Rendah. J IPTEK Terap. 2015;9:1-10.

3. UNICEF. Comitting to Child Survival : A Promised Renewed Progress Report. 2015.

4. Kemenkes. Profil Kesehatan Indonesia 2016. Profil Kesehatan Provinsi Bali. 2017. 1-220 p.

5. Ermalena. Indikator Kesehatan SDGs di Indonesia. Jakarta; 2017.

6. Maryunani A, Nurhayati. Buku Saku Asuhan Bayi Baru Lahir (Asuhan Neonatal). Jakarta: Trans Info Media; 2008.

7. Conde-Aguedelo A, Díaz-rossello JL. Kangaroo mother care to reduce morbidity and mortality in low birthweight infants ( Review ). Cochrane Database Syst Rev. 2016;(8):1-149.

8. Trevisanuto D, Putoto G, Pizzol D, Serena T, Manenti F, Varano S, et al. Is a woolen cap effective in maintaining normothermia in lowbirth-weight infants during kangaroo mother care? Study protocol for a randomized controlled trial. 2016;1-7.

9. Riskesdas. Riset Kesehatan Dasar (Riskesdas 2013). Jakarta: Balitbangkes Kemenkes RI; 2013. $103 \mathrm{p}$.

10. Alasiry E. Profil Bayi Rujukan Saat Masuk Rawat Ditinjau dari the STABLE Program. 2014;13(4):235-8.

11. Nimbalkar SM, Patel VK, Patel D V., Nimbalkar AS, Sethi A, Phatak A. Effect of early skin-to-skin contact following normal delivery on incidence of hypothermia in neonates more than $1800 \mathrm{~g}$ : Randomized control trial. J Perinatol. 2014;34(5):364-8.

12. Suradi R, Yanuarso PB. Metode Kanguru Sebagai Pengganti Inkubator Untuk Bayi Berat Lahir Rendah. 2000;2(1).

13. Sindhu R, Jothi CM. Reducing Early Neonatal Heat Loss in a Low Resourced Context: An Indian Exemplar. 2015;8(1):140-52.

14. Etika R, Roeslani RD, Alasiry E, Endyarni B, Suginarti. Humanity First, Technology Second. Reducing Infant Mortality Rate with Kangaroo Mother Care. Practical Evidence From South Africa. J Empir Res Hum Res Ethics. 2009;45(1):219-24. 
15. Masrukah N. Perbedaan Efektifitas Metode Inkubator Dengan Metode Kangaroo Mother Care Dalam Pencegahan Hipothermia Pada Bayi Dengan Berat Badan Lahir Rendah Di Ruang Neonatus RSUD Sidoarjo. Universitas Airlangga; 2011.

16. Depkes RI. Pedoman Pelayanan Kesehatan Bayi Berat Lahir Rendah (BBLR) dengan Perawatan Metode Kanguru di Rumah Sakit dan Jejaringnya. Jakarta: Departemen Kesehatan Republik Indonesia; 2009.

17. Srinarth B, J S, P K, PS S. Kangaroo care by fathers and mothers: comparison of physiological and stress responses in preterm infants. 2016;

18. Almgren M. Benefits of skin-to-skin contact during the neonatal period: Governed by epigenetic mechanisms? Genes Dis. 2018;5(1):24-6.

19. Etika R, Roeslani RD, Alasiry E, Endyarni B, Suginarti, Bregman. Humanity First, Technology Second" Reducing Infant Mortality Rate With Kangaroo Mother Care: Practical Evidence From South Africa. 2009;45(3):219-24.

20. Baker-rush M, L MSC. Reducing Stress in Infants : Kangaroo Care. 2016;31(4):14-8.

21. Wong D., M H-E, Wilson D, Winkelstein ML, P S. Buku Ajar Keperawatan Pediatrik. Jakarta: EGC; 2009. 294-297 p.

22. Choudhary M, Dogiyal H, Sharma D, Datt Gupta B, Madabhavi I, Choudhary JS, et al. To study the effect of Kangaroo Mother Care on pain response in preterm neonates and to determine the behavioral and physiological responses to painful stimuli in preterm neonates: A study from western Rajasthan. J Matern Neonatal Med. 2016;29(5):826-31.

23. Endhah S. Pengaruh perawatan metode kanguru terhadap stres fisiologis pada bayi berat lahir rendah di RSUD Sukoharjo. Stikes Kusuma Husada Surakarta; 2016.

24. Mazumder S, Taneja S, Dalpath SK, Gupta R, Dube B, Sinha B, et al. Impact of community-initiated Kangaroo Mother Care on survival of low birth weight infants: study protocol for a randomized controlled trial. Trials. 2017 Jun;18(1):1-10.

25. Perinasia. Perawatan Bayi Berat Lahir Rendah (BBLR) dengan Metode Kanguru. Direktorat Jenderal Bina Pelayanan Medik, Depkes RI dan Health Service Program-USAID; 2008. 1-24 p.

26. Boundy EO, Dastjerdi R, Spiegelman D, Fawzi WW, Missmer SA, Lieberman E, et al. Kangaroo Mother Care and Neonatal Outcomes: A Metaanalysis. Pediatrics. 2016;

27. Chan GJ, Valsangkar B, Kajeepeta S, Boundy EO, Wall S. What is kangaroo mother care? Systematic review of the literature. J Glob Health. 2016;6(1):1-9.

28. Zarea K, Beiranvand S, Sheini-Jaberi P, NikbakhtNasrabadi A. Disaster nursing in Iran: Challenges and opportunities. Australas Emerg Nurs J. 2014;17(4):190-6.

29. Gregson S. Kangaroo care in pre-term or low birth weight babies in a postnatal ward. Britsh J Midwifery. 2011;19(9):568-77.

30. Rangey PB, Sheth MS. Comparative Effect of Massage Therapy versus Kangaroo Mother Care on Physiological Responses, Chest Expansion and Body Weight in Low Birthweight Preterm Infants. Disabil CBR Incl Dev. 2014;25(3):103.

31. Emilia 0, Budi Wahyuni R. Faktor-Faktor yang Berhubungan dengan Pernikahan Usia Dini di Kabupaten Purworejo Jawa Tengah. J Ber Kedokt Masy. 2012;25(2):51. 